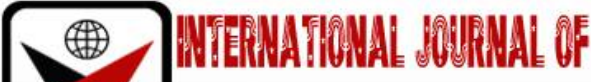

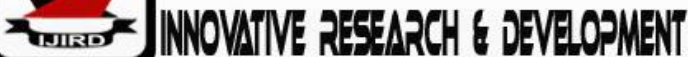

ISSN 2278-0211 (Online)

\section{Language and Characterization in Achebe's A Man of the People}

\author{
John Asiegbor \\ Tutor, Department of Languages, Peki College of Educatio, Ghana \\ Clever Susuawu \\ Tutor, Department of Languages, Peki College of Educatio, Ghana
}

\begin{abstract}
:
This paper pays attention to language and characterization in Achebe's A Man of The People. It is revealed that Achebe uses relatively few women such as: Elsie to represent young unmarried women, Mrs. Agnes Akilo to represent professionals. He also uses Jean to represent whites. Eunice is used to represent the brave and Mrs. Nanga to represent house wives. Also, two different generations of politics are brought to light, namely the new intellectual generation represented by Odili and the old style of bush politics represented by chief. Discussing language and characterization in Achebe's A man of the people, because the author uses both female and male characters, the following female characters had been considered in this write up: Mrs. Nanga, Edna, Elsie, Eunice, Agnes Akilo (the barrister), Mrs. Eleanor John, Jean, Ego Women together with the male characters such as; Chief Nanga, Odili Samalu, Mr. Nwege Chief Koko, Josia The Prime Minister and Mathew. While women are seen as important tools that contribute to men's success in politics, sex tool, influential, people who are stiffened by cultural beliefs, immoral, celebrated trophies, brave, intelligent and obedient, the males on the other hand are seen to be selfish, sexually greedy, wicked, proud, tricky, optimistic, foolish ambitious and oppressors. It is finally revealed that the image of women is generally portrayed as indeterminate human beings, dependent, gullible and voiceless. Paradoxically, it is these same women who are presented as sublime, perfect, beautiful, brave, caring and nurturing.
\end{abstract}

Keywords: Language, characterization, professionals, brave, generations, politics intellectual, generation, oppressors

\section{Introduction}

The novel, by Chinua Achebe casts a critical eye on African politics. The author's eyepiece in A Man of The People is the narrator, Odili, a schoolteacher; the object of his scrutiny is Chief the Honorable M.A. Nanga, Member of Parliament, Odili's former teacher and a popular bush politician who has risen to the post of Minister of Culture in his West African homeland. At first, Odili is charmed by the politician; but eventually he recognizes the extent of Nanga's abuses and decides to oppose the minister in an election. Odili is beaten, both physically and politically, his appeal to the people heard but ignored. The novel demonstrates, according to critic Shatto Arthur Gakwandi, how 'the society has been invaded by a wide range of values which have destroyed the traditional balance between the material and the spiritual spheres of life, which has led inevitably to the hypocrisy of double standards.' Odili is the victim of these double standards.

Despite his political victory, Nanga, along with the rest of the government, is ousted by a coup. The seriousness of the fictional situation portrayed in A Man of the People becomes real very soon after the novel was first published in 1966 when Nigeria itself was racked by a coup.

Also, two different generations of politics are brought to light, namely the new intellectual generation represented by Odili and the old style of bush politics represented by chief Nanga. The bone of contention between these two generations is not only in politics but also on women. Often in Africa, women are devalued and considered second class citizens. They are viewed as objects constructed by men as inconsequential and passive (Akujobi, n. d., 2000) and this is seen in Achebe's A Man of the People. Through history, men are seen as subjects who determine concepts and create structures for others, especially women, to adhere to. This has not helped the woman's image or position (B. A., 1980 as cited by Akujobi). It is in this view that this paper seeks to discuss Language and characterization in Achebe's A Man of The People.

Merriam Webster Dictionary and Wikipedia, the free encyclopedia sees language primarily as the mental faculty that allows humans to undertake linguistic behaviour to learn languages and produce and see it to bea communication of thoughts and feelings through a system of arbitrary signals, such as voice sounds, gestures, or written symbols or the method of human communication, either spoken or written, consisting of the use of words in a structured and conventional way. It is any nonverbal method of expression or communication- 'a language of gesture and facial expression'- the smallest component of written language that has semantic value; refers to the abstract meaning or shape, rather than a specific shape. Characterization on the other hand is the system including the combination of qualities or 
features that distinguished one person, group, or thing from another. The way an author presents characters. It is an instance whereby the author a dramatist gives life to the characters. It is a description of qualities or peculiarities of characters.

Because the author uses both female and male characters, the following female characters would be considered in this write up: Mrs. Nanga, Edna, Elsie, Eunice, Agnes Akilo (the barrister), Mrs. Eleanor John, Jean, Ego Women would be dealt together with the male characters such as; Chief Nanga, Odili Samalu, Mr. Nwege Chief Koko, Josia, The Prime Minister and Mathew.

\section{Discussion}

The Ego Women Party is motivative. This appears when they are presented to spice up an occasion where they welcome Chief the Honorable M. A. Nanga, MP. The women dressed in their expensive costume to make the occasion colorful. One will ask why Achebe projects the women this way but not men.

In the novel, women are not given major roles to play in politics. Women who were seen in the political platform like Mrs. John Eleanor, Edna and Chief Koko's wife have not performed any major role. This is evidenced in the statement made by Mrs. Eleanor:

Wetin wrong with am? Asked Mrs. John. Because na woman get am e no go sweet for mouth. I done talk say na only for election time woman de get equality for dis our country. Chp 1, pg 21

This confirms the fact that women are not regarded at all in politics. Their usefulness comes only when election is around the corner. To buttress this point, chief Koko's wife is also portrayed as the organizer to the Women's Wing of the People's Organization Party (P. O. P) so as to breastfeed the ballot boxes. This can be seen in Cht 13, pg 160

As I got the story ... in an operation that one might describe as breast - feeding the ballot, i.e. smuggling into the polling booths wads of ballot paper concealed in their brassieres.

It is obvious from the above quotation that even though chief Koko's wife is used, she is used for a bad notion to the benefit of selfish male politicians.

On the issue of women in politics, Edna is also used as a decorative object to beautify the dais. Odili points out that there is a beautiful girl in the Minister's party but is not introduced to the audience and even members of the entourage as said by Dogo:

'The Minister no de introduce am to anybody' chp 1,pg 17

This implies that Edna is not respected or regarded by Chief Nanga.

One-way Achebe characterized women in the text is that he projects them as sex tools in the hands of their male counterparts. This is exemplified when Elsie, a female character, is caught between Odili and Chief Nanga. Achebe portrays Elsie as cheap when Odili first meets her. In a matter of an hour, Odili is able to sleep with Elsie. In the same way, Chief Nanga also goes to bed when Elsie pays a visit to Odili in Chief Nanga's house. After this incidence, Achebe ceases to mention Elsie again in the text. Another female character Achebe characterized as a sex tool for their male counterpart is Jean, who even though married is seen having sex with Odili. Chp 5; pg 58.

Women are also painted as influential in the text. It is shown in the text that there is no occasion organized, be it a political rally or election without women playing an influential role. In reference to this, Chief Koko's wife is asked to organize other women during an election year for the success of the election. To add to this, Achebe describes Mrs. John Eleanor as an influential party woman from the coast who comes in the minister's party. Chp1; pg 15

In another situation, Achebe characterized women in the text as being stiffened by their cultural beliefs. This is seen in the case of Mrs. Nanga not becoming happy in her marital home when the husband Chief Nanga brings into the house Edna as his second wife. She could not complain because their cultural beliefs have permitted men to be polygamous. This compels her to introduce Edna as their second wife (chp 3: pg 41) though she is not happy about it.

'As seen as her mother... Let nobody remember the woman who toiled and starved when there was no money...'

Furthermore, women are characterized as immoral. This is evidenced in the text when Elsie sleeps with both Odili and Chief Nanga, a married man. Elsie's case is no exception, Jean, a married woman, is seen to have an affair with Odili in the text. Another instance that also portrays the immorality of women is when Agnes Akilo, the Barrister, sleeps with Chief Nanga. This is confirmed in Odili's statement.

'I had nothing against professional women - in fact, I like them I their way - but if emancipation meant people like that other lady lawyer who came to sleep with illiterate Chief Nanga for twenty-five pounds a time (as he confided to me next morning), then they could keep it.'Chp12; pg 143

Also, Mrs. Eleanor John, has also been seen in the text as one of the women that smokes.

'She sat on the minister's left smoking and fanning herself' chp 1; pg15

In our society, it is culturally immoral for a woman to engage in sexual debauchery as explained above and to also smoke (especially in public). This is why Achebe exposes them to call for a change.

In another development, women are pictured as homemakers as exemplified in Mrs. Nanga's domestic activities, Edna has also taken responsibility of taking care of her sick mother at the hospital. Edna's father also says to Odili that since his wife took ill and was admitted at the hospital, there have not been cola nuts in the house because she used to ensure that there were always cola nuts to welcome visitors with. Women cook and take care of the household chores.

Achebe characterizes the use of women as celebrated trophies in the text. Women dress neatly and beautifully to make every function they attend colorful.

Again, women are portrayed to be brave. This comes to light when Eunice avenges the death of her fiancé, Maxwell Kulamo by shooting Chief Koko. This is an indication that although women are generally seen as weak and used 
by men to accomplish their selfish interests, they can also be very brave and stand for what is right and with this we see a single woman out of the lot being portrayed as a heroine. Even though she goes to jail for that act, she emerges victorious at the end. Wole Soyinka like Achebe projects women as brave. This is seen in his drama entitled Konge's Harvest where Segi (a female character) is bold enough to present a human head as a parcel to the King, Oba Danlola.

Women are also characterized to be intelligent. This could be inferred from where Achebe presents Agnes Akilo as a barrister, a female to occupy a high position in the society; Jean, a diplomat and Eunice, a Lawyer. This means given the opportunity, women can rise as high as their male counterparts in social circles. The writer, goes on to show how the issue of a woman is the main reason for rivalry between a god father and a god son who later contested for the same seat his god father - a constituency.

Achebe highlights the roles of women in the novel as obedient to males and their lives are greatly affected by the desire of their husbands or fathers (Achebe, 2006). This is seen when Mrs. Nanga goes to the home town with the children and leave the man to himself with his friend. Also, Edna is compelled to obey his father's instruction to stay away from Odili and accept to be Chief Nanga's wife. This confirms the assertion of Chukwuma (1994), who states that the female character in African fiction... is a facile lack luster human being, the quiet member of a household... Docility and complete submission of will is demanded and enacted from her.

Talking about the male characters, Chief Nanga is a selfish character. This appears when he uses his position to enrich himself. This appears in these words;

"Tell them that this man had used his position to enrich himself and they would ask you -as my father did- if you thought that a sensible man would spit out the juicy morsel that good fortune place in his mouth." He also uses money to influence people. This appears during the dance at the proprietor's lodge when he gives five pounds to the women's party. He does this in his own interest.

Nanga is a proud character. This is seen in the following words; 'I used to read about him in the papers some years later and even took something like pride in him. pg 3. He claims that they are going to honour him doctorate degree in Law. Nanga is a casanova. This is evidenced in the text when Chief Nanga, a married man sleeps with Elsie. Another evidence is the situation where Chief Nanga sleeps with Agnes Akilo, the Barrister,this is confirmed in Odili's statement.

'I had nothing against professional women - in fact, I like them I their way - but if emancipation meant people like that other lady lawyer who came to sleep with illiterate Chief Nanga for twenty-five pounds a time (as he confided to me next morning), then they could keep it.'Chp12; pg 143

Nanga is partial. This is evidenced when he says Odili should come to the city so that he gets strategic position in the civil service and that they should not leave everything to the highland tribes because his secretary comes from there and that their secretary should press for their fair share of the national cake. He is an optimistic, a determined and an influential character because he still remains the man of the people even though Odili stands against him. He finally wines the election. Even Odili's town people refuse to vote for him as they announce to the people that it is Nanga that they know. This change of mind emerges after portable drinking water is extended to Odilis' village. Nanga is tricky and ironical. This appears when he speaks at the school addressing the staff that he regrets even leaving the teaching profession although he is a minister today; he could swear to God that he is not as happy as when he was a teacher.

Odili Samula is the next character to be discussed. He is an intelligent student in his school days. He wins scholarships and reads post graduate certificate course in London. Odili remarks that he is in the school only because he is able to win a scholarship. Odili also reprimands his father when he wants to marry his fifth wife. He remarks in this word; 'In my anger I said, he was storing up troubles for others'. He is adventurous. This appears when he stands to contest for Chief Nanga's position to the extent that he even goes to his opponent's ralley where he is brutalized severely and his car is destroyed. He is sexually corrupt. This is evidenced in the text when Odili, sleeps with Elsie and Jean, a married woman who is seen to have an affair with Odili in the text. He is a foolish character as goes to the rally of his opponent. He is ambitious as he wants to contest with Nanga. He is also revengeful. This appears when he fights back to take from Nanga who takes his girlfriend. He is also romantic because he says he gets closer to Edna so that he puts his arm over her shoulder, slipped over her breast and he spreads her against her side pg 75. He is a disappointed character because he did not achieve his objective as winning the election but was a victim of his actions. He is influential because he influences Edna not to marry Chief Nanga. Odili appears to be a coward because Nanga wrenches his girlfriend from him and he could not say anything.

Considering the minor characters, Chief Koko causes troubles as he says they want to poison him meanwhile there isn't anything like that. Josiah another character is tricky and wise because he discovers Azoge's plan and manages to take his stick which makes him to get more money. This appears in the following words;

"Josia called Azoge to his shop and gives him rice to eat and plenty of palm wine. Azoge thought he had met a kind man and began to eat and drink While he was eating and drinking, Josia took away his stick and put a new stick like the old one in its place thinking that Azoge would not notice... pg 96.

Mr. Nwege is a proud character. This is because he in the name of introducing the invited guest, spent twenty minutes talking about himself all he had done for the party at Anata and environs. He is also a poor hungry elementary school teacher. Jonathan Nwege and the staff respect the Prime Minister when he visits the school. He insists that the students should mount a ground of honour stretching from the main road to the school door while the teachers are also to stand in a line at the end of the student's queue just to be introduced. This kind of welcome appears likewise to what happens in Julius Caesar in Shakespeare's Julius Caesar when the whole Rome takes a day to welcome Caesar because of his victory that he has over Pompay's two sons.

The Prime minister also exhibits some characteristics. He tells lies. This appears in the following words; 
The minister of finance at the time was a first-rate economist with a PhD in public finance. He presents to the cabinet a complete plan of dealing with the situation. The prime minister said no to the plan. He was not going to risk losing the election by cutting down the price paid to coffee planters at that critical moment. The national bank should be instructed to print fifteen million pounds. Two thirds of the ministers supported the minister. The next morning the minister sacked them and, in the evening, he broadcast to the nation. He said the dismissed minister were conspirators and traitors who had team up with foreign saboteurs to destroy the new nation." This paints a picture of corrupt politics. The media and the news indicate clearly that it is only the minister's version of the story that is presented.

The effect of the minister's action is that, the dismissed minister's car was destroyed. By the angry mob and his house stoned while another dismissed character is also pulled out from his car been insensible dragged along the road for fifteen yards and tied hand and foot gagged and left by the roadside.

Because the Prime minister is proud, he speaks two hours and his very other words is applauded and he is called the Tiger, the Lion, the one and only one, the Sky, the ocean, and many other names of praise.

The author to a very large extent uses language in various ways to achieve his objectives. He uses simple language which could be understood by an average reader though there are some few situations where the words are difficult to understand except the dictionary is consulted. The author to a very large extent uses cod- mixing and cod- shifting. He uses both the English language paripaso the pidgin. Sometimes, he shifts to use either the pidgin alone or the English Language. Wetin wrong with am? Asked Mrs. John. Because na woman get am e no go sweet for mouth. I done talk say na only for election time woman de get equality for dis our country. Chp 1, pg 21

Achebe uses a lot of proverbs. To exemplify, let us take these words into consideration.

- 'If you respect today's king others will respect you when your turn comes'.pg 70

- 'The minister's flag could pass through the eye of a niddle'.pg 32

- 'But there was really no hard kennel of fact to get one's teeth into' pg 45

- 'When one slave sees another cast into a shallow grave, he should know that when the time comes, he will go the same way' $\mathrm{pg} 40$

- 'It is only when you are close to a man that you can begin to smell his breath'. Pg 121

- 'When those standing have not got their share, you are talking about those kneeling'. Pg 126

- 'The food is cooked and the smell of the food is around'. pg135

- 'The tick fills its belly with blood from the back of the bull and the bull doesn't even know it's there'. pg119.

- 'If Alligator comes out of the water one morning and tells you that crocodile is sick, can you doubt his story?'141

- 'If the very herb we got seek in the forest now grows at our very back yard, are we not saved the journey?' 141

- 'There are no two things you could do to yam - if you don't boil it you roast it.'pg143

Achebe uses these proverbs to add taste to the text in such a way that the readers enjoy reading this novel. He uses metaphors, similes, imageries, symbolisms suspense and many other figures of speech to achieve his objectives.

\section{Conclusion}

It could be concluded from the discussion that Achebe uses relatively few women such as: Elsie to represent young unmarried women, Mrs. Agnes Akilo to represent professionals, Jean to represent whites Eunice to represent the brave and Mrs. Nanga to represent house wives Also, two different generations of politics are brought to light, namely the new intellectual generation represented by Odili and the old style of bush politics represented by chief. Discussing language and characterization in Achebe's A man of the people, because the author uses both female and male characters, the following female characters had been considered in this write up: Mrs. Nanga, Edna, Elsie, Eunice, Agnes Akilo (the barrister), Mrs. Eleanor John, Jean, Ego Women together with the male characters such as; Chief Nanga, Odili Samalu, Mr. Nwege Chief Koko, Josia The Prime Minister and Mathew. While women are seen as important tools that contribute to men's success in politics, sex tool, influential, people who are stiffened by cultural beliefs, immoral, celebrated trophies, brave, intelligent and obedient, the males on the other hand are seen to be selfish, sexually greedy, wicked, proud, tricky, optimistic, foolish ambitious and oppressors.

From the above discussion, it is obvious that the image of women is generally portrayed as indeterminate human beings, dependent, gullible and voiceless. Paradoxically, it is these same women who are presented as sublime, perfect, beautiful, brave, caring and nurturing. (Ruth, 20011).

\section{References}

i. Achebe, C (1966), A Man of the People. African Writers Series.

ii. Achebe, C (2006), Portrayal of women in Igbo Society. Writework.com

iii. Akujobi, R. (n.d.) (2000). Re-evaluating female inferiority: The image of women in Habila's waiting for an angel and Agary's YellowYellow. A paper submitted to the Dpt. of Languages, College of Development Studies, Covenant University, Ota, Ogun State, Nigeria.

iv. Chukwuma, H. (1994). Feminism and African Literature. Enugu New Generation Books.

v. Merrian, Website and the free encyclopedia1993-2007 Microsoft Corporation.

vi. Ruth S. (2001). Issues in Feminism: An introduction to women's studies. $5^{\text {th }}$ ed. California Mayfield Publication Company. 
vii. Soyinka, W. (1965). Konge’s Harvest. African Writers Series.

viii. The Free on-line dictionary 1993-2007 Microsoft Corporation. 